\title{
CEFERINO SUÁREZ BRAVO AL COMPÁS DE LOS TIEMPOS: EL TIGRE Y LA ZORRA, REESCRITURA DEL TEXTO DRAMÁTICO LOS DOS COMPADRES, VERDUGO Y SEPULTURERO
}

\author{
Fátima Codeseda Troncoso \\ Universidad de Vigo
}

\begin{abstract}
Resumen
Ceferino Suárez Bravo, erudito ovetense de mediados del XIX, no será ajeno al tiempo de inestabilidad política y social en el que vive, y publica, con motivo de las revueltas que precedieron a la segunda guerra carlista, el drama Los dos compadres, verdugo y sepulturero. Es este argumento el que le servirá reelaborado, años más tarde, para un poema del estilo de los grandes romances históricos de Rivas, Espronceda o Zorrilla. El tigre y la zorra, divulgado en el Semanario Pintoresco Español, representa este el auge del Romancero, así como de la fábula, la leyenda y la temática medieval, con Álvaro de Luna y Juan II como telón de fondo.

Palabras clave: Suárez Bravo, romance, drama, Álvaro de Luna, política, historia
\end{abstract}

\begin{abstract}
Ceferino Suárez Bravo, an Ottoman scholar from the mid-nineteenth century, will not be unaware of the time of political and social instability in which he lives, and published, in the wake of the revolts that preceded the Second Carlist War, the drama Los dos compadres, verdugo y sepulturero. It is this argument that will serve, reworked, years later for a poem of the style of the great historical romances of Rivas, Espronceda or Zorrilla. El tigre y la zorra, published in the Semanario pintoresco español, represents from this the rise of the romancero, as well as from the fable, the legend and the medieval theme, with Álvaro de Luna and Juan II as a backdrop.
\end{abstract}

KeY Words: Suárez Bravo, romance, drama, Álvaro de Luna, politics, History

\section{Ceferino Suárez Bravo, alias Ovidio el Romo}

La inestabilidad ideológica y social que caracteriza al siglo XIX funciona 
como caldo de cultivo para numerosas divulgaciones con un marcado carácter político ${ }^{1}$. Ceferino Suárez Bravo, intelectual ovetense decimonónico con una intensa actividad literaria y periodística, no es ajeno al tiempo en el que vive y protagoniza con sus creaciones numerosas polémicas. Como articulista participa en publicaciones periódicas como El Contemporáneo, El Pensamiento, Español, El Fénix o La España y cofunda a mediados de siglo El Padre Cobos, diario satírico de signo conservador y fuertemente crítico con el gobierno progresista de Espartero. Tras unos años alejado de la vida pública, en los que ostenta el cargo de cónsul en Génova, participa en ciertos periódicos como El Siglo Futuro, en el que concurre, a partir de 1877, con el seudónimo Ovidio el Romo ${ }^{2}$.

Será precisamente en estos años, y a través de dicho pseudónimo, cuando tendrán lugar algunas de las polémicas de mayor trascendencia. Clarín, detractor confeso de Suárez Bravo, ya en 1876, en el diario El Solfeo, intenta ridiculizar el lenguaje de este como respuesta a uno de sus artículos: «dejo demostrado que el Sr. Ovidio es un soldado raso de la literatura y que no da pieses con bola» ${ }^{3}$.

Sus primeras incursiones en prensa como literato tendrán lugar en El Nalón, con una serie de textos poéticos que presentan notables influencias de los grandes románticos españoles: Espronceda, Zorrilla y Rivas. El léxico tremendista, así como los numerosos sucesos amorosos, abocados normalmente al fracaso, y semejantes a los utilizados en los romances históricos del duque de Rivas, caracterizan parte de estos poemas iniciales ${ }^{4}$.

Aunque ya en 1851 había publicado El cetro y el puñal, ensayo de su narrativa posterior, será la reciente segunda guerra carlista la que le proporcionará la idea para una verdadera novela. Así concibe Guerra sin cuartel, publicada en 1855 no sin cierta polémica, en la que da cuenta de lo acontecido en la primera guerra carlista, e introduce, al compás de los hechos reales, elementos posibles pero ficticios. Aunque los diarios afines al carlismo aplaudieron el texto de Suárez Bravo, los liberales se convirtieron en

\footnotetext{
${ }^{1}$ Este trabajo se inserta en el ámbito investigador del proyecto FFI-2015-64107-P (MINECO/FEDER, $\mathrm{UE})$.

${ }^{2}$ G. Cazottes y E. Rubio Cremades, «El auge de la prensa periódica», en V. García de la Concha (dir.), Historia de la Literatura Española. Siglo XIX, Madrid, Espasa Calpe, 1997, pp. 43-59; J. M. Martínez Cachero, «Más noticias para la bio-bibliografía de Ceferino Suárez Bravo», en El canto de las sirenas: páginas de investigación y crítica, Oviedo, Universidad de Oviedo, 2000, pp. 505-522; y M. J. Vilar, «Testimonio y documentos. El exilio español en vísperas del destronamiento de Isabel II, visto por el dramaturgo y periodista Ceferino Suárez. Cónsul de España en Bayona», en Migraciones y exilios: Cuadernos de la Asociación para el estudio de los exilios y migraciones ibéricos contemporáneos, 14 (2014), pp. 127-146.

${ }^{3}$ L. Alas, Clarín, «Ovidio el Romo», El Solfeo, 431 (1876), p. 1.

${ }^{4}$ J. M. Martínez Cachero, ob. cit., pp. 505-507.
} 
Ceferino Suárez Bravo al compás de los tiempos: El tigre y la zorra, reescritura del texto dramático Los dos...

detractores del mismo ${ }^{5}$. De igual modo, la marcada postura antinaturalista que Bravo demuestra en el prólogo de la novela puede que sea la causa de la dura crítica que de nuevo recibe de su contemporáneo Clarín 6 .

No obstante, en esta línea romántica despuntará, sobre todo, como dramaturgo. En la década de los 40 se producen grandes modificaciones en lo que concierne a las compañías teatrales, hecho que permite un cambio significativo en el repertorio. Aunque los teatros del Príncipe y de La Cruz mantienen su privilegiado puesto como principales salas, se crean nuevas compañías y escenarios, a la vez que se componen y representan obras originales de corte nacional, restando así importancia a las traducciones y refundiciones. Este contexto favorece, a partir de 1845, la composición por parte de Suárez Bravo de los textos El bufón del Rey, Enrique III, Mujer y madre o El Dos de Mayo, así como las comedias Un motín contra Esquilache y El lunar de la marquesa.

Mención especial merece Los dos compadres, verdugo y sepulturero, drama en un acto, estrenado en 1848 y objeto de múltiples polémicas. Como ya había ocurrido con otras obras que circulaban en la época -El puñal del godo, de Zorrilla, por ejemplo-, el reducido número de personajes espoleó su representación por parte de numerosas compañías, hecho que convirtió el drama en seña distintiva del autor para múltiples críticos de la época. En un artículo del diario La Unión, su redactor habla de Ovidio como de «el autor de Los dos compadres, verdugo y sepulturero»; e incluso Clarín en sus escritos de El Solfeo y Nueva Campaña hará referencia a Suárez Bravo con tal mención ${ }^{8}$.

Es el romance uno de los subgéneros de mayor relevancia a mediados del XIX. Ya en las primeras décadas se publican en España numerosos volúmenes recopilatorios de romances viejos y nuevos, siguiendo la estela de la Silva de romances viejos de Grimm, como la Colección de los más célebres romances antiguos españoles, históricos y caballerescos de Depping (1825), la Colección de romances antiguos de Durán (1828-1832) y el Tesoro de los Romanceros y Cancioneros Españoles compilado por Ochoa (1838). Se convertirá así en uno de los moldes predilectos para jóvenes románticos como Rivas, Espronceda o

\footnotetext{
${ }^{5}$ L. Alas, Clarín, Nueva campaña (1885-1886), Madrid, Imprenta de Enrique Rubiños, 1887, pp. 40-174; y J. M. Martínez Cachero, ob. cit., pp. 516-522.

${ }^{6}$ Para referirse a dicha novela, afirma Clarín que solo por la supremacía de la minoría de malos y pésimos académicos se explica «que la Academia Española haya podido premiar la novela de don Ceferino Suárez Bravo, titulada Guerra sin cuartel... Título incompleto: Guerra sin cuartel a la gramática y a toda clase de literatura, debiera llamarse el libro que premió la Academia» (ob. cit., p. 173).

${ }^{7}$ Anónimo, «La metamorfosis de Ovidio», La Unión, 279 (1879), p. 1.

${ }^{8}$ L. Alas, Clarín, art. cit., p. 1; L. Alas, Clarín, ob. cit., pp. 40-174. Otro tanto sucede en el siglo xx: N. Díaz de Escovar y F. P. Lasso de la Vega, Historia del teatro español. Comediantes, escritores, curiosidades escénicas, Barcelona, Montaner y Simón, Tomo II, 1924, pp. 16-72; D. T. Gies, El teatro en la España del siglo XIX, Cambridge, Cambridge University Press, 1996, pp. 245-260; J. M. Martínez Cachero, ob. cit., p. 509; F. Rodríguez García, Galería de españoles ilustres y distinguidos: continuación de apuntes anteriores, Cebú (Filipinas), El boletín de Cebú, 1893, p. 1378.
} 
Zorrilla, que asumirán la creación de nuevas composiciones. La búsqueda del espíritu nacional que protagonizan los máximos representantes del Romanticismo justifica la predilección que estos sienten por los grandes acontecimientos del pasado. De ello deriva la trascendencia del romance de tipo histórico, transmisor de los principales acontecimientos del medievo, con el Cid, Pedro i de Castilla y Álvaro de Luna como principales protagonistas 9 .

El protagonismo de don Álvaro de Luna, condestable de Juan II de Castilla, se extiende a otros géneros literarios y sirve de herramienta para establecer paralelismos entre la inestabilidad política y social del XIX y lo acaecido en tiempos del maestre. Corrobora este hecho la publicación en 1830 de Los Bandos de Castilla, obra centrada en la corte de Juan II y, sobre todo, en Álvaro de Luna, y que sienta un precedente argumental para textos que se divulgarán en los años siguientes: leyendas, romances -como el que Rivas incluye como apéndice a El moro expósito (1834)-, ensayos - sirva de ejemplo el que Quintana realiza sobre el condestable en Vida de Españoles Célebres (1833)-, novelas -las de Fernández y González o Torrijos- o los dramas de la tercera década del siglo: El condestable de Castilla, de Bonilla (1838), Los cortesanos de don Juan II (1839), de Morán y Don Álvaro de Luna (1840) de Gil y Zárate. Y mientras en unos Luna representa las injusticias de su tiempo, en otros encarna la arrogancia de los que, por sus ansias de grandeza, usurpan el poder real y conducen el reino a la guerra y a la ruina moral $^{10}$.

\section{LOS DOS COMPADRES, VERDUGO Y SEPULTURERO. DRAMA EN UN ACTO ORIGINAL Y EN VERSO}

Es este tema histórico, es decir, las circunstancias que rodean el ajusticiamiento del condestable, el que sirve a Suárez Bravo de excusa para llevar a escena una nueva pieza teatral: Los dos compadres, verdugo y sepulturero. Drama en un acto original y en verso. Se representa por primera vez en el teatro del Instituto de Madrid, el 22 de febrero de

\footnotetext{
${ }^{9}$ A. Amorós, Antología comentada de la literatura española. Siglo XIX, Madrid, Castalia, 1999, pp. 192-202; S. García Castañeda, «Introducción», en Ángel Saavedra, duque de Rivas, Romances históricos, Madrid, Cátedra, 1987, pp. 11-71.

${ }^{10} \mathrm{M}$. Ceide Rodríguez, «El Romanticismo y la recuperación de la materia medieval: el caso de J. Morán», en R. Hernández Arias, G. Rivera Rodríguez, S. Cuba López y D. Pérez Álvarez (eds.), Nuevas perspectivas literarias y culturales. Actas I CIJIELC, Vigo, MACC-ELICIN, 2016, pp. 105-113, aquí p. 109; F. Codeseda Troncoso, «Álvaro de Luna y su tiempo como metáfora de un mundo en crisis: periodismo, política y literatura en el siglo XIX español», en F. López Criado (ed.), El arte en un mundo en crisis: La literatura, el cine y la prensa como instrumentos de transformación social, Santiago, Andavira, 2016, pp. 249-260; M. Ribao Pereira, «Prensa, actualidad política y romanticismo español: el caso de J. Morán y la corte de Juan II de Castilla», Amnis [En línea], 14 (2015). URL: https://amnis.revues.org/2541; M. Ribao Pereira, « Y si el corazón miente? Los (falsos) poetas de la corte de Juan II vistos por los románticos», en Antonella Cancellier (ed.), El corazón es centro, Padua, EPU, 2017 (en prensa); y M. Ribao Pereira, «Intrigas desde el lecho: perversiones cortesanas en El condestable de Castilla (1858), novela de Manuel Torrijos», en J. Avilés Diz (ed.), Perversiones decimonónicas, Valencia, Albatros, 2017 (en prensa).
} 
Ceferino Suárez Bravo al compás de los tiempos: El tigre y la zorra, reescritura del texto dramático Los dos...

1848, con una aparente buena acogida ${ }^{11}$. Así lo recoge en esos días el Heraldo:

Anteanoche se estrenó en el Instituto el drama nuevo del joven literato don Ceferino Suárez Bravo titulado: Los dos compadres. Esta producción tuvo la acogida que merecía, habiendo sido muy aplaudida y su autor llamado a escena ${ }^{12}$.

Tiene lugar la representación de la obra en medio las revueltas francesas que terminaron con el reinado de Luis Felipe de Orléans en el país vecino y con los prolegómenos de las que tendrían lugar meses más tarde en el nuestro. El descontento civil por la crisis que atraviesa el país coincide con el segundo levantamiento carlista, causa que abordará años más tarde Suárez Bravo en la tan criticada novela Guerra sin cuartel $^{13}$.

Se anuncian en el inicio de la obra, tras el dramatis personae, el lugar y tiempo en el que se ambienta la acción: «Valladolid en el año de 1453 y día de la ejecución de don Álvaro de Luna» ${ }^{14}$. No es la primera vez que el autor se ocupa de lo acontecido en el entorno cortesano de los Trastámara, ya que un año antes (1847) había llevado a los teatros D. Enrique III, drama original, en tres actos y en verso, hecho que pone de relieve el interés que este período histórico de la Castilla medieval despierta en Bravo.

En el caso que nos ocupa, la muerte de don Álvaro sirve de desencadenante para la puesta en escena de personajes de baja condición, aparentemente irrelevantes en cuestiones palaciegas. La obra gira en torno al sepulturero Garduña, su compadre Juan Castrillo -verdugo de Valladolid-y el hijo de este último, Tomás, horas antes de la ejecución del maestre. La acción comienza con la llegada de Garduña a casa de su compadre, donde mantiene una importante conversación con Tomás. Por herencia, su futuro oficio será el de verdugo de la ciudad, tarea que detesta y por la que desea morir, harto de vivir rodeado de muerte y del miedo de sus vecinos. No obstante, el sepulturero parece centrarse en otro asunto de mayor enjundia: evitar el ajusticiamiento del condestable don Álvaro de Luna. Un embozado le ofrece una buena cantidad a cambio de terminar con la vida del verdugo, su compadre Castrillo. El rey está indeciso y si consiguen posponer el ajusticiamiento unas horas, puede que don Álvaro se salve. Así, el sepulturero urde su plan con el embozado: un asesino esperará a Castrillo en

\footnotetext{
${ }^{11}$ E. Miralles, «Catálogo de obras de teatro del siglo XIX por autores asturianos», Cuadernos para la Investigación de la Literatura Hispánica, 28 (2003), pp. 241-328, aquí p. 268. J. M. Martínez Cachero, en un estudio anterior al de Miralles, no coincide con esta fecha y señala como año de estreno 1850 (ob. cit., p. 509).

${ }^{12}$ Anónimo, «Gacetilla de la capital», Heraldo, nº 1756 (1848), p. 4.

${ }^{13}$ R. Sánchez Mantero, Historia de España. La España de Isabel II. De la Regencia de María Cristina a la Primera República (1833-1874), Madrid, Espasa Calpe, 1999, p. 72.

${ }^{14}$ C. Suárez Bravo, Los dos compadres, verdugo y sepulturero. Drama en un acto, original y en verso, Salamanca, Establecimiento tipográfico de Oliva, 1863, p. 6. En adelante cito por esta edición del texto.
} 
una calle poco transitada y allí terminará con su vida. Garduña será el encargado de conducir a su amigo al lugar acordado. Pero antes de que el verdugo salga en busca de la muerte, habla con su compadre sobre la procedencia de su hijo: Tomás es de origen noble, recogido de pequeño por Garduña y entregado a Castrillo para que lo cuide como suyo. Tras esta conversación es herido el verdugo y en su agonía aparece otro embozado que busca sustituto para ajusticiar al maestre. Resulta ser el conde de Castro, padre sin saberlo de Tomás. Se revela en ese instante el origen del joven, que sigue a su verdadero progenitor y se salva de tan vil oficio, dejando a Garduña en el puesto que ansiaba desde un principio: verdugo de Valladolid y encargado de la ejecución del maestre.

Esta historia se traslada a escena en un solo acto, fragmentado en quince escenas de diversa extensión. Coincide la brevedad de la obra con el reducido número de personajes que Suárez Bravo emplea para su representación, siete en total -Castrillo, Garduña, Tomás, el conde de Castro, dos embozados sin nombre y una voz-, aunque solamente los tres primeros son relevantes para los acontecimientos escenificados.

Resulta significativa la imagen que del pueblo se ofrece en el drama, bien conocida por los aficionados a las leyendas, género en boga en el Romanticismo y que, como veremos más adelante, da sentido a la reescritura de la obra unos años más tarde. La leyenda funciona en la sociedad decimonónica como "punto de referencia», como un modo de «rescatar el espíritu del pueblo» ${ }^{15}$, ideas estas que preocupaban a los eruditos del momento. La narración tradicional se transmite de generación en generación y es rescatada en el Romanticismo para su reelaboración culta. Este origen popular explica la presencia de personajes y hechos verdaderos o verosímiles, con los que la comunidad se identifique: «seres reales sacados del pasado», ligados a «un lugar concreto [...] así como a un tiempo determinado» ${ }^{16}$. De este modo, los textos se colman de referencias a sucesos o tiempos conocidos, de forma que, como asegura Keen, lo fantástico no reste credibilidad a lo contado, y favorezca la faceta aleccionadora de tales textos. Asimismo, el género funciona como denuncia y sátira en momentos difíciles y como ejemplo de valores y principios para la sociedad en la que se origina ${ }^{17}$.

Suárez Bravo redacta un texto plagado de puntos de encuentro con el espectador, tanto en el tema que aborda como en los personajes y en los lugares que en él plantea. Como antes mencionaba, en los años previos a su representación son múltiples los eruditos románticos que, a través de romances, novelas u obras

\footnotetext{
${ }^{15}$ S. P. Liso, La leyenda culta en España durante el período romántico, Ohio, Universidad de Ohio, 2001, aquí p. 34.

${ }^{16}$ S. P. Liso, ob. cit. p. 32.

${ }^{17}$ M. Keen, The Outlaws of Medieval Legend, Londres, Routledge, 1987, aquí p. 212.
} 
Ceferino Suárez Bravo al compás de los tiempos: El tigre y la zorra, reescritura del texto dramático Los dos...

dramáticas, dan a conocer al público de la época lo acontecido al condestable de Juan II de Castilla. Este hecho convierte el inicio y trasfondo argumental de Los dos compadres en algo ya conocido por el receptor de la época, así como algunos de los personajes que intervienen a lo largo de la representación, como el conde de Castro. Del mismo modo, sus protagonistas se dedican a oficios marcados significativamente en los textos románticos: el verdugo, que ya había popularizado Espronceda, y el sepulturero. A su vez, en concordancia con los acontecimientos históricos, los hechos se sitúan en la ciudad de Valladolid, lugar de referencia real para el público de la época.

A semejanza de las leyendas románticas, en la obra el pueblo se contrapone a la nobleza, de modo que ambos grupos se encuentran ante la imposibilidad de modificar su situación social: «el que nace dentro del pueblo, crece y muere dentro de él, y sus hijos heredan esta situación», así como el noble lo es «de hecho y de derecho» ${ }^{18}$. En Los dos compadres se representan los dos estratos sociales, unidos en la figura de Tomás. El hijo de Juan Castrillo rechaza aquello que le corresponde por herencia, el oficio de verdugo. El propio Tomás, en una de sus intervenciones expone:
TomÁs: Sí.
¿No he de odiar lo que provoca en contra mía el desprecio de los hombres? ¿Qué afrentosa máscara llevo en mi rostro, que do quiera que me topa todo el mundo con horror vuelve la faz desdeñosa? Dime, Garduña ¿tal vez somos nosotros, importa que la verdad no me ocultes, de otro barro, de otra forma que los demás hombres? (Los dos compadres, ob. cit., p. 9).

Este hecho choca con las convenciones estamentales medievales que antes mencionaba como constante en las leyendas decimonónicas. Para paliar este desajuste se introduce en el drama un personaje perteneciente al estamento noble, que resulta ser el padre de Tomás y que, de algún modo, justifica la negativa de este ante tan vil oficio: es noble de hecho y de derecho y, aunque criado por un miembro del pueblo llano, sus instintos y ademanes son propios de un personaje de abolengo.

Capaz de terminar con la vida de sus semejantes con tal de conseguir lo que se propone ${ }^{19}$, el sepulturero representa en la obra la barbarie con la que se conduce el vulgo en diversos textos de la época. Garduña actúa movido por la avaricia, por sus

\footnotetext{
${ }_{18}^{18}$ S. P. Liso, ob. cit., pp. 219-220.

${ }^{19} \mathrm{Idem}$. p. 220.
} 
ansias de conseguir una suculenta recompensa y alcanzar, a su vez, uno de los puestos de más fama en la ciudad de Valladolid, el de verdugo ${ }^{20}$. No obstante, la culpa del sepulturero se atenúa gracias a la petición que este realiza al embozado: la amistad que le une a su compadre le impide ejecutar la obra, por lo que prefiere que otro sea el que la lleve adelante ${ }^{21}$.

Por tanto, Garduña, sepulturero de la ciudad de Valladolid, se presenta como el protagonista del drama, compadre del verdugo y encargado de retrasar la ejecución del condestable de Juan II. Representado como un personaje movido por la ambición, Garduña hila la trama de forma que siempre sale beneficiado, tanto en lo económico como en la posición social. El fin de todo el entramado es llegar a ejercer un oficio que todo el mundo teme. Así se constata en la recta final del drama si tomamos en consideración una de las conversaciones entre el conde de Castro y Garduña:

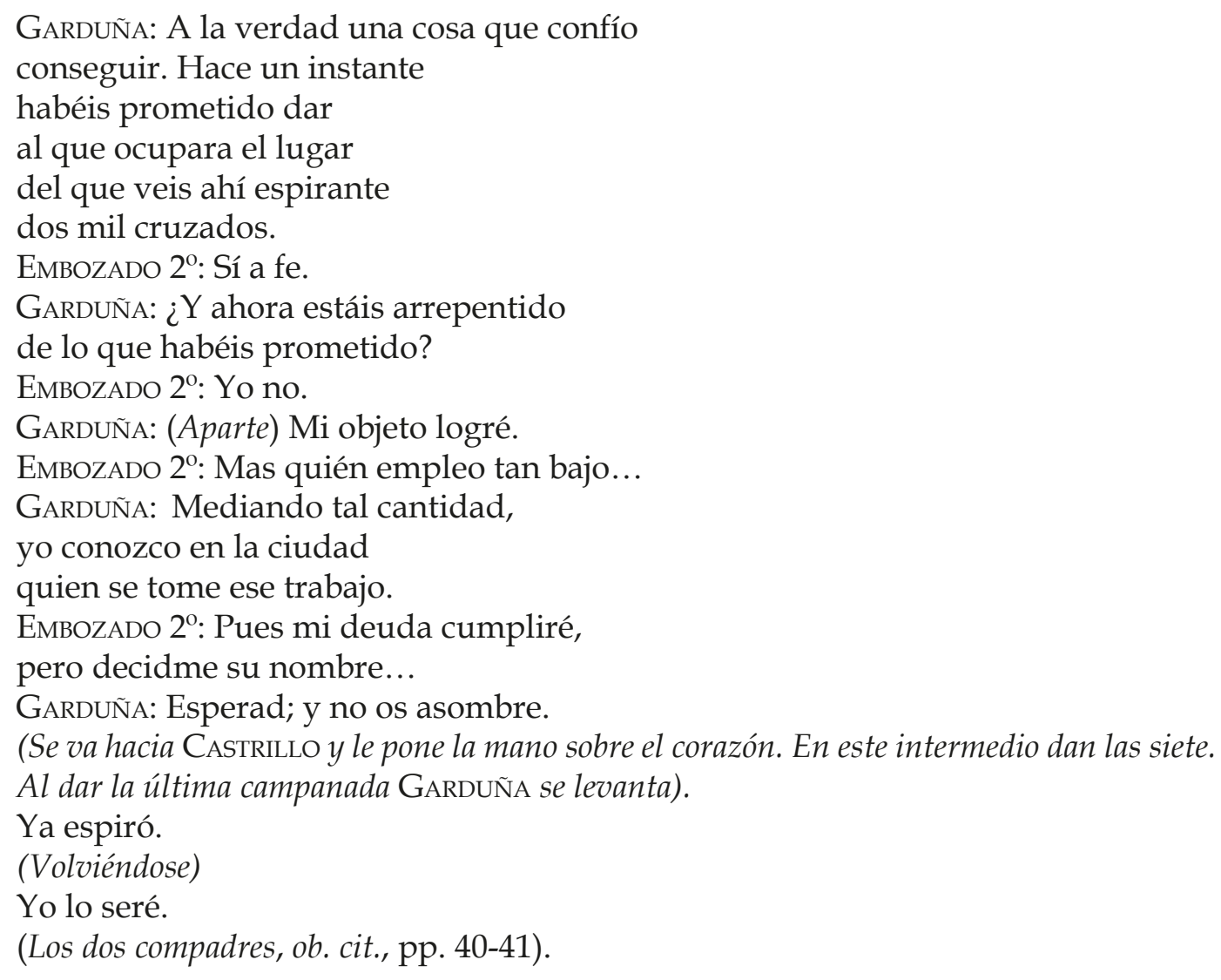

Y a continuación leemos en la intervención del sepulturero:

GARDUÑa: (Solo) De gozo el mancebo salta: ¡hágale el diablo feliz!

\footnotetext{
${ }^{20}$ S. P. Liso aborda este hecho como ejemplo de barbarie, aunque, a su juicio, sea Garduña el que termina con la vida de su compadre (ob. cit., p. 220).

${ }^{21}$ De esta manera se verifica en el texto: «EMBOZADO $1^{\circ}$. ¿Queréis ser vos el que ponga? / GARDUÑa. No... que al fin es mi compadre /y la amistad me lo estorba; / pero hallaréis quien lo haga/ siempre que el dinero corra». (Los dos compadres, ob. cit., p. 14).
} 
Ceferino Suárez Bravo al compás de los tiempos: El tigre y la zorra, reescritura del texto dramático Los dos...

Con agüero favorable

mi nuevo trabajo empieza.

¡Oh, dejará mi destreza

satisfecho al condestable!

Así, aunque falte Castrillo,

honraré su oficio al menos.

(Los dos compadres, ob. cit., p. 42).

Castrillo, verdugo de Valladolid y encargado de terminar con la vida del maestre, no interviene en la acción hasta la quinta escena. Aunque Garduña alude a su compadre en los diálogos que mantiene con Tomás y con el embozado, la atención se centra en la artimaña del sepulturero, hecho que en un primer momento relega al verdugo a un segundo plano. Es su puesto el objetivo del conflicto y en torno al que se mueven el resto de personajes, pero sus limitadas intervenciones, de escasa trascendencia, le restan intensidad dramática.

Tomás, el tercer protagonista de la obra, se presenta en un primer momento como hijo de Castrillo, aunque será este vínculo uno de los motores del drama: se trata del instrumento que Garduña utiliza para conseguir su ansiado propósito de gloria. El ya citado rechazo que siente el hijo del verdugo por el oficio de su padre será, junto con su verdadero origen, el soporte perfecto para los planes de Garduña. De esta manera, el personaje de Tomás va unido al del sepulturero en casi la totalidad del drama, funcionando como nexo entre los personajes de baja condición y los nobles de Castro y Luna. Ello se identifica, como veremos a continuación, con el contexto político y social del momento de la representación: aquellos que de forma interesada acaparan el poder terminan en el cadalso, mientras que los que fueron despojados injustamente de lo que les corresponde terminan por recuperar su posición ${ }^{22}$.

Resulta fundamental también, por tanto, el conde de Castro, cuarto y último personaje identificado con nombre propio. Se trata de Diego Gómez de Sandoval, personaje histórico, con gran presencia en la Crónica de don Álvaro de Luna, editada en 1784 por Josef Miguel de Flores, como opositor del rey don Juan II de Castilla y de su condestable $^{23}$. El ajusticiamiento de don Álvaro se sitúa en el inicio de la obra como

\footnotetext{
${ }^{22}$ Así se verifica en palabras de Castrillo, en un intento de evitar que se descubra la verdad: «JuAN: [...] Ve ahora..., no seas prolijo..., / donde tu padre se esconde... / y dile... al altivo conde... / Embozado 20: (Aparte) jQué oigo! / Juan: Yo soy... vuestro hijo, / porque es conde, sí, Tomás... / de ilustre y antigua raza. / Émulo del que... en la plaza... / tú mismo a degollar... / vas» (Los dos compadres, ob. cit., p. 38).

${ }^{23}$ J. M. de Flores, Crónica de don Álvaro de Luna, Madrid, Imprenta de Sancha, 1784. Leemos en dicha crónica un enfrentamiento entre el maestre y el Conde de Castro, por defender a su rey don Juan del rey de Navarra: «Muy clara e manifiesta fue la grande lealtad e puro amor que el condestable con Álvaro de Luna tovo siempre al rey e de como en todo tiempo sirvió al rey su señor [...]. Donde como en el año del Nascimiento del Señor de mil cuatrocientos e cuarenta e un años, el condestable [...] sopiese que tenían cercado al rey en la villa de Medina del Campo el rey de Navarra [...] e los Condes de Castro e de Benavente, e $[\ldots]$ como bueno e leal vasallo, ayuntó luego su gente, $[\ldots]$ e vino a todo andar a Medina
} 
introducción de una historia aparentemente poco conocida para el público, acaecida a personajes de baja clase, carentes de trascendencia histórica. Sin embargo, a medida que avanza la trama, la ejecución, aunque siempre presente, va cediendo terreno a la vida y entresijos de estos seres vulgares, introduciendo al espectador en un mundo desconocido. Es en la recta final cuando entra en escena el conde de Castro, personaje acaso reconocido por el público de la época, opositor del condestable y que acerca y devuelve lo sucedido al plano de lo pretendidamente histórico.

En efecto, en el drama se percibe claramente a Castro como el oponente del condestable, ya que su entrada en escena es uno de los obstáculos para el retraso de la ejecución. Sus esfuerzos por cumplir la orden de ajusticiamiento se ven reforzados por las intenciones de Garduña. Dichos personajes parecen tener una clara lectura en clave actual: la defensa de los estamentos medievales y la justicia de origen real, frente a la barbarie del vulgo.

Es este sentido el que cobra mayor relevancia en la representación del drama en plenas revueltas carlistas, previas al estallido de la guerra ${ }^{24}$, así como el apoyo a esta causa que el autor muestra años más tarde en Guerra sin cuartel. Resulta llamativo que uno de los personajes principales, Tomás, se encuentre en una situación que no le corresponde, fuera del lugar que merece por derecho de sangre. Sin embargo, los acontecimientos se precipitan de forma inesperada, la verdad termina por salir a la luz y le ofrece la posibilidad de recuperar aquello que se le había arrebatado desde el nacimiento, es decir, su puesto como heredero del condado de Castro.

Si se establece un paralelismo con los ideales carlistas, este hecho parece adquirir un sentido completo en la obra de Suárez Bravo. Carlos, heredero legítimo antes de la aprobación de la Pragmática Sanción, que permitía gobernar a Isabel II, es relegado a un segundo plano tras la muerte de Fernando viI y se enfrenta a la regente María Cristina. El descontento de algunos sectores, partidarios de Carlos, desemboca en la sucesión de hasta tres guerras, con las que se intenta devolver al justo heredero lo que es suyo (como en el caso de Tomás) según los preceptos del Antiguo Régimen ${ }^{25}$.

Representa el conde de Castro la nobleza de sangre, de derecho, que consigue recuperar de forma inesperada al hijo perdido poco después de nacer. A su vez, el personaje de Álvaro de Luna, cuyo ajusticiamiento funciona como contexto de este

del Campo, por fallarse en aquellos trabajos con el rey su señor» (ob. cit. p. 134).

${ }^{24}$ J. Larráyoz Zarranz, «La segunda guerra carlista en Navarra», Príncipe de Viana, 63 (1956), pp. 167-197. Señala Larrálloz Zarranz que «tanto las victorias de los matinés en Cataluña, como la proclamación de la república francesa - febrero de 1848 - resultaban dos factores adversos para el gobierno de Madrid» (ob. cit., p. 184).

${ }^{25}$ J. M. Martínez Cachero, ob. cit., 516-522; R. Sánchez Mantero, ob. cit., 13-74. 
Ceferino Suárez Bravo al compás de los tiempos: El tigre y la zorra, reescritura del texto dramático Los dos...

suceso, podría ser la imagen de aquellos que por usurpar el poder real terminan en el cadalso. Es Isabel, con respecto a la causa carlista, la usurpadora del poder real, la que sin atenerse a las leyes del Antiguo Régimen se impone ante el heredero legítimo, Carlos

\section{El TigRE Y LA ZORRA}

En 1852, tras un tiempo de representación del drama Los dos compadres, Suárez Bravo divulga, repartida en diversos números del Semanario Pintoresco Español, la composición El tigre y la zorra. Leyenda tradicional $^{26}$. Se trata de un texto en versos variados, con predominio del romance, que reconstruye el argumento de Verdugo y sepulturero, acercándolo a las fábulas que circulan en la época. El Semanario se reafirma como diario apolítico, aunque se preocupa por los asuntos morales, tanto públicos como privados. Ello justificaría, en parte, que los personajes nobles pierdan protagonismo para cedérselo a aquellos en que se centraban las leyendas decimonónicas ${ }^{27}$.

Coincide dicha publicación con los años posteriores al término de la segunda guerra carlista (1846-1849). La efímera contienda, de menor repercusión que la primera o la que tendría lugar en los 70, finaliza con la victoria de los isabelinos. La pérdida de una parte de su vigencia favorece la reelaboración argumental de Los dos compadres en un nuevo texto ${ }^{28}$.

Así, el poema de Bravo narra lo acontecido al verdugo de Valladolid, Castrillo, a su hijo Tomás y a su compadre, el sepulturero Garduña, momentos antes de la ejecución de Luna. En este caso, prescinde el autor de varios personajes, entre los que destaca el conde de Castro, uno de los elementos fundamentales en el drama. De este modo, el asunto del origen de Tomás se difumina y adquiere mayor relevancia lo sucedido a los vulgares protagonistas. Garduña, movido por su avaricia, urde un plan con el que acabar con la vida de su compadre y así recibir la recompensa que un embozado le ofrece a cambio. El objetivo es retrasar el ajusticiamiento del condestable, ya que, como ocurría en Los dos compadres, el rey está indeciso. No obstante, en El tigre y la zorra se hacen más patentes las intenciones de Garduña, pues el puesto de verdugo es desde un primer momento su principal anhelo. $Y$ al desaparecer el conde de Castro del relato, es el propio Tomás el que se quita la vida, dejando vía libre al sepulturero.

\footnotetext{
${ }^{26}$ Semanario Pintoresco Español, 1, 4 de enero (1852), pp. 7-8; 2, 11 de enero (1852), pp. 15-16; 3, 18 de enero (1852), pp. 23-24; 4, 25 de enero (1852), p. 32; 6, 8 de febrero (1852), p. 47.

${ }^{27}$ G. Cazottes y E. Rubio Cremades, ob. cit., pp. 46-59; S. P. Liso, ob. cit., 32-223; y F. Codeseda, ob. cit.

${ }^{28}$ J. Lárrálloz Zarranz, ob. cit., p. 167-197; J. M. Martínez Cachero, ob. cit., 516-522; y R. Sánchez Mantero, ob. cit., 13-74.
} 
La disposición y caracterización de los personajes obedece a lo que el texto adelanta en título y subtítulo: El tigre y la zorra, protagonistas comunes en las fábulas de finales del XVIII y principios del XIX, en las leyendas tradicionales, género en boga en el romanticismo y en el que ya había fundamentado Bravo el drama. El éxito de las fábulas ilustradas se prolonga hasta principios del XIX, años de inestabilidad política y social en los que el género se promueve como intento de reforma y enseñanza ${ }^{29}$. El tigre y la zorra son eje de múltiples composiciones de este tipo, ya que encarnan, para los escritores y lectores de la época, la fuerza y el poderío, el uno, y la astucia, la otra. Así configura Bravo un poema en el que, con su sola mención, se anuncia a los lectores la caracterización física y psicológica del verdugo y del sepulturero. Castrillo es la representación del fiero y vanidoso tigre, temido por todo el pueblo de Valladolid ${ }^{30}$ :

Era Castrillo un jayán

de fornida catadura, barba poblada y oscura, resuelto y torvo ademán.

[...] Su mirada escrutadora el vulgo medroso huía, porque del tigre tenía

la vista fascinadora.

[...] Lo abyecto y ruin de su estado no le infunde sentimiento, que era por temperamento

a la sangre aficionado.

(4 de enero [1852], p. 7).

Garduña, en consecuencia, es la imagen de la astuta zorra, que, sin utilizar la fuerza, consigue a través de inteligentes artimañas sus propósitos de grandeza. La descripción del primer capítulo así lo advierte:

Para obtener su figura,

forja, lector, en tu mente un

ser flaco, transparente de muy

mediana estatura.

[...] Dale afilada nariz,

y orna esta faz silenciosa de una

barba vedijosa

de indefinible matiz.

Larga y estrecha pezuña, mano

\footnotetext{
${ }^{29}$ R. Valvidares, Fábulas satíricas, políticas y morales sobre el actual estado de Europa, 1811. R. Valvidares, recopilador decimonónico del género, afirma en uno de sus volúmenes que, en relación con la situación político-social de su tiempo, «la venenosa hidra de la discordia» que ha levantado su cabeza sobre todos los tronos de la tierra; en que vacila y titubea la fidelidad mas acrisolada; en que la ambición y el egoísmo arrastran a los hombres tras del carro violento de un tirano usurpador; en que al patriotismo y fortaleza han sustituido la perfidia y una flaqueza criminal; en una palabra, en unos tiempos en que casi todos los hombres se han desnudado de los sublimes sentimientos de honor, de religión y aun del amor debido a sus verdaderos intereses; no hallo ciertamente otro remedio más adecuado que el presente contra un cáncer tan contagioso, después de ver frustrados los más poderosos y eficaces» (Valvidares, ob. cit., pp. 18-19).

${ }^{30}$ El texto que cito es accesible en red desde el portal de la Hemeroteca Digital de la Biblioteca Nacional de España. En adelante cito fecha y página de publicación a que me refiero.
} 
Ceferino Suárez Bravo al compás de los tiempos: El tigre y la zorra, reescritura del texto dramático Los dos...

que a la de un difunto se acerca,

$\mathrm{y}$ tal en conjunto es la imagen de

Garduña.

(4 de enero [1852], p. 7).

Por tanto, el autor reescribe el argumento de Verdugo y sepulturero con una clara diferencia: ahora ya no son relevantes los asuntos nobles y los personajes que adquieren verdadera importancia son los de baja condición. Ello concuerda con el subtítulo del texto, en el que se advierte al receptor que se trata de una leyenda tradicional. Como ya había hecho en el drama, Suárez Bravo introduce en el poema elementos que vinculan al lector con la realidad histórica, tanto en la temática como en los espacios y personajes. Así, añade a la ciudad de Valladolid el río Esgueva y eleva a su vez el protagonismo del verdugo, sujeto de interés para los románticos, como ya he mencionado a propósito del drama.

Como resultado, se diluye en El tigre y la zorra la contraposición entre los personajes nobles y el pueblo, para focalizar casi en exclusiva las acciones de este último. Mientras que en el drama la nobleza de sangre, representada en el personaje de Tomás, se superponía a la crianza, el vulgo centra la atención del poema de 1852 y se acentúa la barbarie con la que actúa. Solo se conserva del drama, en este sentido, la negativa de Tomás a asumir el cargo del verdugo que su padre le deja en herencia. Junto a ello, pasa desapercibida la cita del noble corazón de Tomás, que únicamente podrán interpretar como linaje aquellos lectores de la fábula conocedores del drama:

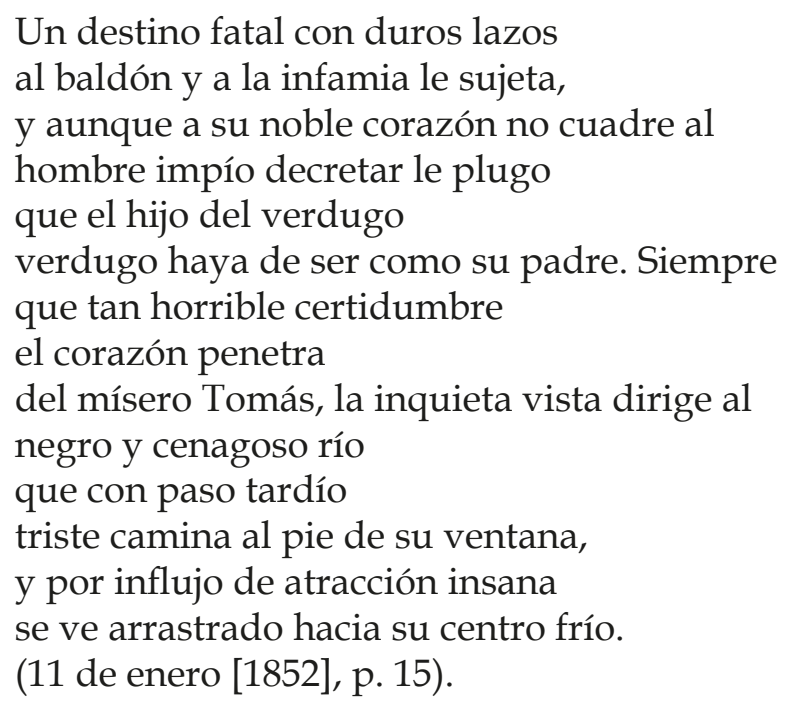

Como ya constatamos en estas palabras, la única solución que el hijo de Castrillo encuentra para sus terribles tormentos es el suicidio ${ }^{31}$. Así, leemos en los versos finales:

\footnotetext{
${ }^{31}$ S. P. Liso recoge en sus estudios este hecho, citando la obra de Suárez Bravo como ejemplo de leyenda castellana decimonónica protagonizada por el pueblo, en la que los personajes principales se encuentran atrapados en el destino que su origen vulgar les impone (ob. cit., p. 219).
} 


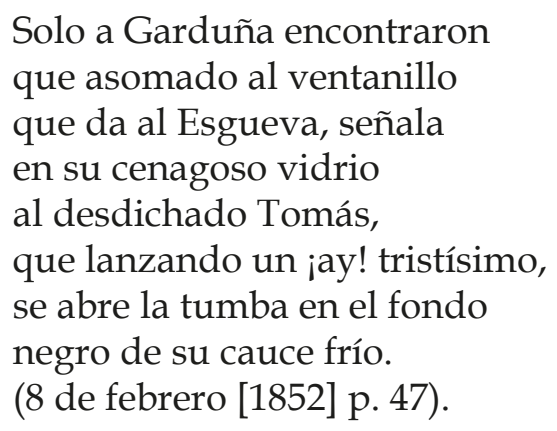

De este modo, se sustituye en la composición del Semanario la acción del conde de Castro por el suicidio de Tomás. Así se consigue que, tanto en el drama como en su traslado al poema narrativo, el final sea el mismo. Aunque la nobleza pierda relevancia en el segundo, hecho quizás fomentado por el fin de la guerra carlista, se mantiene la actuación bárbara del sepulturero y del pueblo de Valladolid. A juicio de Liso, en multitud de textos decimonónicos se presenta al vulgo como capaz de acabar con la vida de sus camaradas y vecinos ${ }^{32}$. Sea como fuere, Bravo muestra en ambas composiciones a un Garduña que consigue matar indirectamente a su compadre para alcanzar sus objetivos. En el poema, sin embargo, se acentúa la actuación del primero en esa muerte, determinada por el carácter violento que las leyendas les atribuyen a los personajes de baja condición. El protagonismo de verdugo y sepulturero en la reescritura del texto primigenio le ofrece a Garduña la intensificación de su avaricia, propia como ya señalamos de su imagen fabular de zorra. El regocijo que en él produce ser, por fin, el verdugo de la villa vallisoletana, se constata en los versos finales de la obra, tras el suicidio de Tomás:

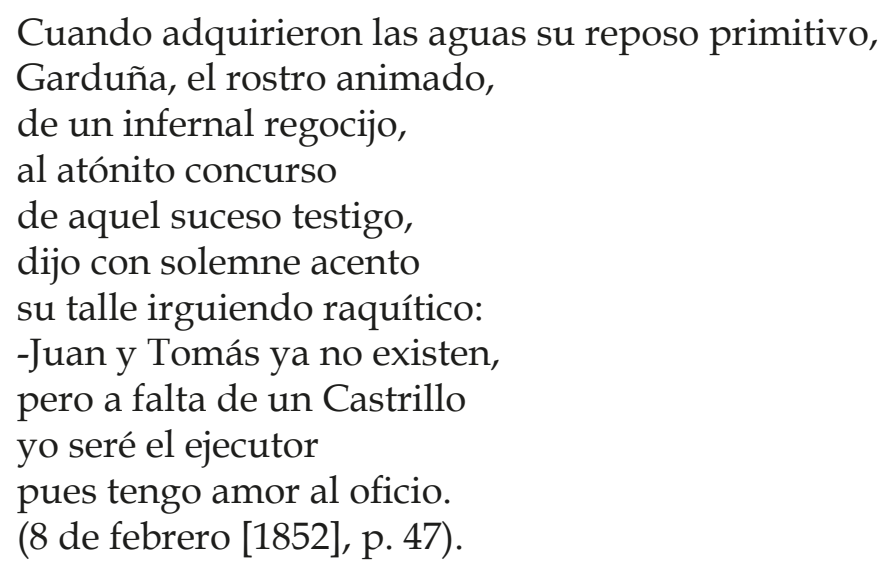

El pueblo, a su vez, actúa como Garduña, complementando las acciones de este. El deseo del primero de ver en el patíbulo a un noble de renombre como Luna le lleva a terminar con la vida de Castrillo y a proporcionarle así al sepulturero el anhelado puesto. La función del vulgo en el romance se refuerza, con respecto al drama, gracias al linchamiento del verdugo y a la persecución que sobre Tomás tiene lugar y que

\footnotetext{
${ }^{32}$ S. P. Liso, ob. cit., p. 220.
} 
Ceferino Suárez Bravo al compás de los tiempos: El tigre y la zorra, reescritura del texto dramático Los dos...

termina por abocarle al suicidio ${ }^{33}$.

En consecuencia, El tigre y la zorra se configura de forma diferente con respecto al drama. En este caso, tras la reciente derrota carlista, Bravo presenta un texto en el que conjuga fábula y leyenda, géneros que le permiten presentar en escena ciertos tipos literarios asociados a determinadas lecciones morales.

Don Álvaro de Luna es el único personaje noble que se conserva en el argumento del poema, funcionando como desencadenante de los acontecimientos. La actuación del conde de Castro en Verdugo y sepulturero remarcaba la presencia del condestable en todo el drama, debido a los intentos de su adversario por cumplir la sentencia de ejecución. Y aunque en el romance la muerte del maestre pasa a un segundo plano, sigue siendo su ajusticiamiento el hecho que suscita las intrigas ideadas por Garduña. De hecho, en la narración, a diferencia del drama, se dedican unos versos a la exposición de los motivos que llevan al noble Luna al cadalso,

El mismo día en que al noble condestable, aquel robusto guerrero y privado insigne, llevó a cadalso de luto la ingratitud soberana del rey don Juan el Segundo. (4 de enero [1852], p. 7).

Del mismo modo, el salvajismo con el que actúa el pueblo es espoleado por la satisfacción que en él produce presenciar el sacrificio de un noble de tanto prestigio:

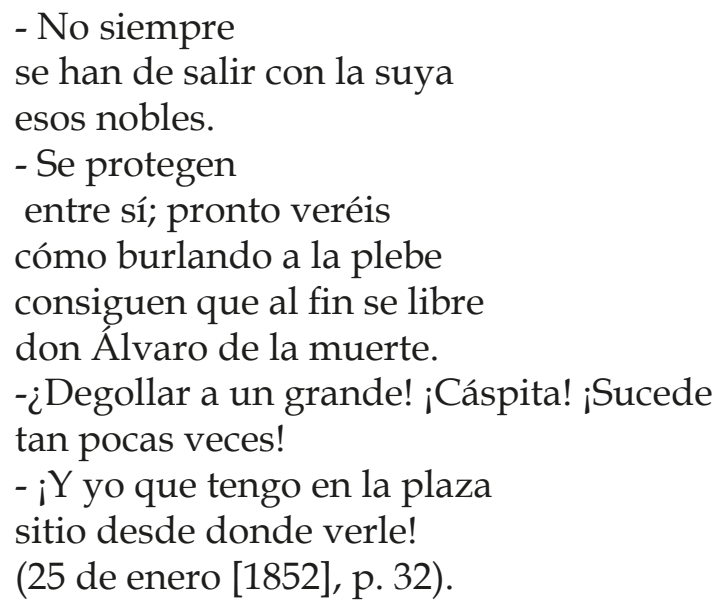

\footnotetext{
${ }^{33}$ Ejemplo de ello son los versos que recrean la demanda del heredero del verdugo: «-Amigos, -con voz robusta / gritó un cortador de siete / pies de estatura y de formas / atléticas- me parece / que se pierde el tiempo: en tanto / que gritáis como mujeres, / se pone en salvo el rapaz, / y no habrá quien dé la muerte / al condestable. / -No, no / - bramó la turba-. ¡A prenderle! / -Sepamos si está en la casa» (25 de enero [1852], p. 32). Y el fin de la persecución: «Su desesperada queja / hubo apenas concluido / el desdichado mancebo / cuando al compás de los gritos / del populacho cruel / que bulle fuera intranquilo / en la puerta resonaron / tres golpes, y a un tiempo mismo / abrid a la ley, con dura / precisión una voz dijo» (8 de febrero [1852], p. 47).
} 
Este hecho histórico ya se adelantaba en el planteamiento didascálico del drama a continuación del dramatis personae. En el romance, sin embargo, se amplía la información con un capítulo inicial al que llama Suárez Bravo «Introducción» y en el que se orienta al lector de la composición. Advierte a este del contenido y, sobre todo, le sitúa en tiempo y espacio: Valladolid en tiempos de Juan II. Así, se configura la acción en torno a un suceso real, conocido por el público de la época y que, por tanto, difícilmente se podría modificar, lo que explica que la resolución del conflicto sea el cumplimiento de la sentencia.

En cuanto al molde estrófico que escoge Ceferino Suárez Bravo para divulgar el ya citado argumento, resulta reseñable la polimetría con que ajusta el texto teatral al género poético. Si bien integra en El tigre y la zorra la redondilla en el primer capítulo, la silva en el segundo o la quintilla en el cuarto, la prevalencia del romance sobre otras estrofas convierte este poema en un texto narrativo semejante a los conocidos romances históricos de Rivas ${ }^{34}$.

\section{Conclusiones}

En definitiva, en un tiempo convulso, de continuos cambios políticos y sociales, Ceferino Suárez Bravo sigue la estela de los grandes románticos y adapta uno de sus textos de mayor repercusión al contexto sociopolítico en que se gesta. La tradición romanceril que aborda lo acontecido al condestable, así como los dramas de la tercera década del siglo que giran en torno a la figura del maestre, las novelas y ensayos de esos años, le ofrecen la posibilidad de acercar al público ciertas ideas y lecciones políticas.

Al abrigo del segundo levantamiento carlista, Bravo consigue llevar a escena un drama en el que se contraponen la nobleza y el pueblo llano. Aunque bajo los designios del poder real, ambos grupos luchan por sus intereses, bien a través de una buena cantidad de monedas, bien urdiendo inteligentes artimañas. Sea como fuere, es la sangre la que determina a cada individuo. Tomás, vulgar hijo de verdugo por crianza, termina por encontrar a su verdadero padre y se sitúa en el escalafón que le corresponde por linaje. Del mismo modo, Garduña, sepulturero de Valladolid y por lo tanto personaje perteneciente al más bajo de los estamentos, aspira a ser verdugo de la ciudad, oficio que considera de mayor peso, pero igualmente bajo.

La contienda carlista, que en esos momentos se encuentra en plena ebullición,

\footnotetext{
${ }^{34}$ Este hecho no resulta novedoso en la trayectoria del autor. Ya en sus primero años como poeta, divulga una composición, El castillo de Priorio, que subtitulaba como "cuento» y que encabezaba con una «Introducción» alusiva a la historia medieval real del objeto literario. A su vez, continuaba su composición como un «largo poema polimétrico, con preponderancia del verso octosilábico» (J. M. Martínez Cachero, ob. cit., p. 507).
} 
Ceferino Suárez Bravo al compás de los tiempos: El tigre y la zorra, reescritura del texto dramático Los dos...

le ofrece al drama una especial significación: la defensa de los ideales del Antiguo Régimen, encarnados en Carlos, legítimo heredero para una parte de los intelectuales en ese momento, entre los que se encuentra Suárez Bravo.

Sin embargo, la derrota del bando carlista resta vigencia a la obra y favorece la reelaboración del texto por parte de su autor. El molde escogido es el poético, en el que se introducen, además de la leyenda, elementos fabulares con los que refuerza el papel aleccionador de la composición. Es el molde formal escogido, así como el cambio de contexto político social en el que se divulga, lo que fomenta la supresión del tema estamental y, por tanto, la simplificación de su argumento. En plenas revueltas, es el drama político el que más puede interesar y gustar al público. Por contra, en tiempos de moderantismo es posible que la mejor forma de acercarse a él sea a través de fórmulas reconocibles como la fabulística. Asimismo, el marcado catolicismo de Suárez Bravo, junto a su postura crítica con el progresismo, quizás le lleve a formular su protesta a través de dos textos en los que el vulgo actúa salvajemente, buscando el linchamiento de sus semejantes, o de aquellos a los que detestan, solo por disfrute. Y aunque dichos personajes vulgares centren exclusivamente El tigre y la zorra, persisten en la narración ciertas lecciones dramáticas, como la de la nobleza de sangre -Tomás se suicida ante un oficio que detesta y que no le corresponde-, la continua opresión en que vive el vulgo, la brutalidad de este o la prevalencia de la justicia real sobre el resto de individuos.

Pese a las variantes introducidas, se mantiene inalterado el acontecimiento histórico que rodea a los protagonistas. Este hecho justifica, quizás, la denominación de «leyenda tradicional para referirse al poema: los lectores del mismo, posiblemente, ya conocen su argumento bien por la circulación oral, bien por haber asistido a su representación teatral años antes.

Ceferino Suárez Bravo construye así un argumento literario divulgado de dos formas bien diferenciadas, en el que confluyen otras disciplinas, como la política o la historia. Reescribe el texto al compás de los tiempos sin dejar de lado la tradición literaria de sus contemporáneos. De esta manera, Los dos compadres y su reelaboración narrativa funcionan como ejemplo del acervo literario desconocido aún del XIX y, sobre todo, como muestra del tratamiento estético de lo histórico al servicio de la denuncia política y social.

\section{Bibliografía}

ANÓNIMO, «Gacetilla de la capital», Heraldo, no 1756, 24 de febrero (1848), p. 4. , «La metamorfosis de Ovidio», La Unión, 279, 2 de agosto (1879), p. 1. 
Alas, Clarín, L., «Ovidio el Romo», El Solfeo, 431, 12 de diciembre (1876), p. 1. , Nueva campaña (1885-1886), Madrid, Imprenta de Enrique Rubiños, (1887).

Amorós, A., Antología comentada de la literatura española. Siglo XIX, Madrid, Castalia, 1999. Cazottes, G. y E. Rubio CREMAdes, «El auge de la prensa periódica», en V. García de la Concha (dir.), Historia de la Literatura española. Siglo XIX, Madrid, Espasa Calpe, 1997, pp. 43-59.

Ceide Rodríguez, M., «El Romanticismo y la recuperación de la materia medieval: el caso de J. Morán», en R. Hernández Arias et al. (eds.), Nuevas perspectivas literarias y culturales. Actas I CIJIELC, Vigo, MACC-ELICIN, 2016, pp. 105-113.

Codeseda Troncoso, F., "Álvaro de Luna y su tiempo como metáfora de un mundo en crisis: periodismo, política y literatura en el siglo XIX español», en F. López Criado (ed.), El arte en un mundo en crisis: La literatura, el cine y la prensa como instrumentos de transformación social, Santiago, Andavira, 2017, pp. 249-260.

Díaz de Escovar, N. y F. P. Lasso de la Vega, Historia del teatro español. Comediantes, escritores, curiosidades escénicas, Barcelona, Montaner y Simón, Tomo II, 1924.

Flores, J. M. de, Crónica de don Álvaro de Luna, Madrid, Imprenta de Sancha, 1784.

García Castañeda, S., «Introducción», en Ángel Saavedra, duque de Rivas, Romances históricos, Madrid, Cátedra, 1987, pp. 11-71.

GIES, D. T., El teatro en la España del siglo XIX, Cambridge, Cambridge University Press, 1996.

KeEn, M., The Outlaws of Medieval Legend, Londres, Routledge, 1987.

LARRÁyoz ZARRANZ, J., «La segunda guerra carlista en Navarra», Príncipe de Viana, 63 (1956), pp. 167-197.

Liso, S. P., La leyenda culta en España durante el período romántico, Ohio, Universidad de Ohio, 2001.

Martínez Cachero, J. M., «Más noticias para la bio-bibliografía de Ceferino Suárez Bravo», El canto de las sirenas: páginas de investigación y crítica, Oviedo, Universidad de Oviedo, 2000, pp. 505-522.

Miralles, E., «Catálogo de obras de teatro del siglo XIX por autores asturianos», Cuadernos para la Investigación de la Literatura Hispánica, 28 (2003), pp. 241-328.

Ribao Pereira, M., «Prensa, actualidad política y romanticismo español: el caso de J. Morán y la corte de Juan II de Castilla», Amnis [En línea], 14 (2015), URL: https://amnis.revues.org/2541

Ribao Pereira, M., «¿Y si el corazón miente? Los (falsos) poetas de la corte de Juan II vistos por los románticos», en A. Cancellier (ed.), El corazón es centro, Padua, EPU, 2017, (en prensa).

, «Intrigas desde el lecho: perversiones cortesanas en El condestable de Castilla (1858), novela de Manuel Torrijos», en J. Avilés Diz (ed.), Perversiones decimonónicas, Valencia, Albatros, 2017, (en prensa). 
Ceferino Suárez Bravo al compás de los tiempos: El tigre y la zorra, reescritura del texto dramático Los dos...

Rodríguez García, F., Galería de españoles ilustres y distinguidos: continuación de apuntes anteriores, Cebú (Filipinas), El boletín de Cebú, 1893.

SÁnchez Mantero, R., Historia de España. La España de Isabel it. De la Regencia de María Cristina a la Primera República (1833-1874), España, Espasa Calpe, 1999.

SuÁrez Bravo, C., «El tigre y la zorra», en Semanario Pintoresco Español, 1, 4 de enero (1852), pp. 7-8; 2, 11 de enero (1852), pp. 15-16; 3, 18 de enero (1852), pp. 23-24; 4, 25 de enero (1852), p. 32; 6, 8 de febrero (1852), p. 47. Los dos compadres, verdugo y sepulturero. Drama en un acto, original y en verso, Salamanca, Establecimiento tipográfico de Oliva, 1863.

VAlvidAREs, R., Fábulas satíricas, politicas y morales sobre el actual estado de Europa, 1811.

VILAR, M. J., «Testimonio y documentos. El exilio español en vísperas del destronamiento de Isabel II, visto por el dramaturgo y periodista Ceferino Suárez. Cónsul de España en Bayona», Migraciones y exilios: Cuadernos de la Asociación para el estudio de los exilios y migraciones ibéricos contemporáneos. 14 (2014), pp. 127-146. 